\title{
A caged DAMGO for selective photoactivation of endogenous mu opioid receptors
}

\section{Authors}

Xiang $\mathrm{Ma}^{1}$, Xinyi Jenny He${ }^{1}$, Matthew R. Banghart ${ }^{*}$

${ }^{1}$ Division of Biological Sciences, Neurobiology Section, University of California San

Diego, La Jolla, CA 92093, USA

*Correspondence: mbanghart@ucsd.edu 


\begin{abstract}
:
Photoactivatable drugs and peptides are valuable tools that can drive quantitative studies into endogenous receptor signaling in relatively intact tissue preparations with high spatiotemporal resolution. We previously developed photoactivatable or "caged" variants of the opioid neuropeptides [Leu5]-enkephalin and dynorphin A (1-8), but these reagents activate multiple opioid receptors simultaneously upon photolysis. To achieve selective engagement of mu opioid receptors (MORs), here we describe a photoactivatable derivative of the MOR-selective peptide agonist [D-Ala ${ }^{2}, \mathrm{~N}-\mathrm{MePhe}^{4}$, Gly-ol]-enkephalin (DAMGO). Starting from commercially available DAMGO, we appended a negatively charged carboxynitroveratryl (CNV) caging group to the Nterminal tyrosine side chain (Y) to produce CNV-Y-DAMGO. Dose-response curves in a heterologous functional assay revealed that CNV-Y-DAMGO is $\sim 1$,ooo-fold less potent than DAMGO at MORs. In acute hippocampal brain slices, CNV-Y-DAMGO photoactivation with ultraviolet light resulted in rapid, transient suppression of inhibitory synaptic transmission, and this was blocked by the MOR-selective antagonist CTAP. These results validate CNV-Y-DAMGO as a photopharmacological reagent for manipulating endogenous MOR signaling in brain tissue with light.
\end{abstract}

KEYWORDS: caged compounds, photopharmacology, opioid, synaptic transmission, neurophysiology 


\section{INTRODUCTION}

Photoactivatable or "caged" ligands are powerful tools for probing receptor signaling in living systems (Ellis-Davies, 2007; Paoletti, Ellis-Davies and Mourot, 2019). Because photorelease is typically faster than the biological processes under study, preequilibration of the caged molecule followed by photolysis can provide a robust stimulus that facilitates quantitative analysis of downstream processes. Caged molecules are compatible with more intact ex vivo tissue preparations such as brain slices, and can even work in vivo in intact organisms (Font et al., 2017; Taura et al., 2018).

The mu opioid receptor (MOR) is an inhibitory, $\mathrm{G}_{\mathrm{i} / \mathrm{o}}$-coupled $\mathrm{G}$ protein-coupled receptor (GPCR) that is widely expressed in the nervous system. MORs are the primary target of opioid analgesics such as morphine and fentanyl, and are activated by the endogenous opioid neuropeptides enkephalin, beta-endorphin and dynorphin (Toll et al., 1998; Gomes et al., 2020). Activation of MORs typically leads to the suppression of neuronal excitability and synaptic output. Because MORs are often expressed in inhibitory interneurons, MOR agonists can lead to an increase in circuit output through the disinhibition of projection neurons (Nicoll, Alger and Jahr, 1980; Banghart et al., 2015). In response to sustained activation, MORs undergo acute desensitization on the timescale of minutes, as well as long-term downregulation on the timescale of days (Quillinan et al., 2011). As these molecular processes are relevant to clinical opioid use, either for treating pain or in the context of opiate drug abuse, understanding the basic molecular mechanisms of MOR signaling and their adaptations to chronic activation are of great significance. Furthermore, MORs can interact with other receptors in the nervous system, including other GPCRs such as the delta opioid receptor (DOR), and the N-methyl-D-Aspartate receptor (Kow et al., 2002; Rodríguez-Mũoz et al., 2012; Cahill and Ong, 2018).

The ability to detect changes in MOR signaling in response to processes such as chronic activation or functional interactions with other receptors can be greatly facilitated by the availability of photopharmacological probes such as caged ligands (Williams, 2014; Arttamangkul et al., 2018; He et al., 2021). Ideal tools would enable endogenous MORs to be stimulated in relatively intact brain tissue preparations such as brains slices in a 
manner that is highly reproducible, temporally precise (i.e. not diffusion limited), readily varied in magnitude (i.e. concentration), and compatible with experimental approaches such as electrophysiology and fluorescence imaging. To facilitate studies into opioid receptor signaling in the nervous system, we have developed several caged opioid ligands, including the neuropeptide agonists [Leu5]-enkephalin (LE) and dynorphin A (1-8) (Dyn8), as well as the antagonist naloxone (Banghart and Sabatini, 2012; Banghart et al., 2013; Banghart, He and Sabatini, 2018). Although LE activates MORs with nanomolar affinity, it also activate DORs in a similar concentration range (Toll et al., 1998; Banghart and Sabatini, 2012; Gomes et al., 2020). Therefore, selective stimulation of MORs using caged LE requires the inclusion of a DOR-selective antagonist (Banghart, He and Sabatini, 2018). This requirement adds cost and technical challenges, as optimal antagonists are not inexpensive and can interfere with biological processes mediated by endogenous peptidergic tone. Furthermore, it greatly complicates experiments that intend to specifically probe functional interactions between MORs and DORs, as MORs can only be probed selectively when DORs are blocked (He et al., 2021).

To simplify experiments involving the activation of MORs with caged peptide agonists, we developed a caged analogue of the MOR-selective peptide agonist [D-Ala ${ }^{2}, \mathrm{~N}-$ MePhe4, Gly-ol]-enkephalin (DAMGO) (Handa et al., 1981). As DAMGO is an enkephalin derivative that was designed to resist proteolysis, it shares a cageable pharmacophore with LE and Dyn8. This new reagent, dubbed CNV-Y-DAMGO, can be photoactivated with millisecond flashes of ultraviolet (UV) light in brain tissue to stimulate endogenous mu opioid receptors with high spatiotemporal precision.

\section{RESULTS AND DISCUSSION}

Our caged DAMGO design is based on our prior success in caging LE (1) by appending a carboxy-nitrobenzyl caging group to the N-terminal tyrosine phenol to produce (carboxy-nitrobenzyl)-tyrosine-LE or CYLE (2, Scheme 1) (Banghart and Sabatini, 
2012). The presence of a phenolic proton at this position facilitates high affinity interactions between opioid ligands and opioid receptors through formation of a hydrogen bond in the orthosteric binding site (Manglik et al., 2012). Given the high structural similarity between DAMGO (3) and $\mathrm{LE}$, we reasoned that the presence of a caging group at this site would similarly reduce the

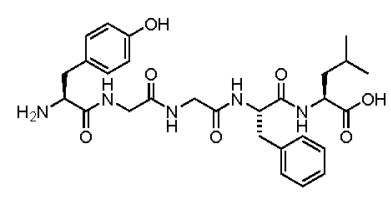
[Leu']-enkephalin (LE)

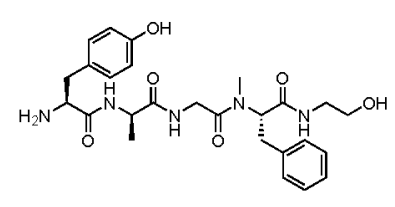

[D-Ala2, N-MePhe4, Gly-olfenkephalin

\section{Scheme 1. Design of a caged DAMGO based on} caged [Leu5]-enkephalin. affinity of DAMGO for MOR. In

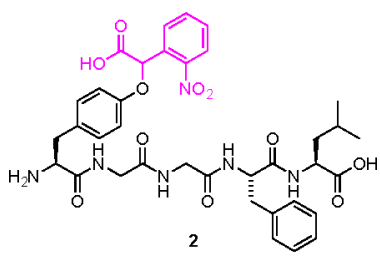

(carboxy-nitrobenzyl)-tyrosine LE

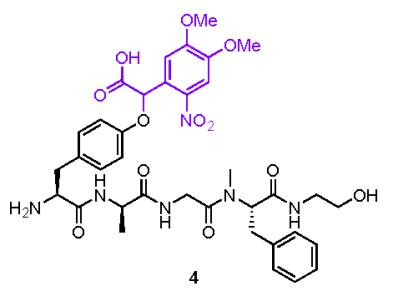

(carboxy-nitroveratry)-tyrosine DAMGO
(CNV-Y-DAMGO) this case, we chose to use the carboxy-nitroveratryl (CNV) caging group, as it includes a negatively charged carboxylic acid to facilitate solubility, and because it exhibits an absorbance tail that enables photolysis with $405 \mathrm{~nm}$ light. Importantly, we previously found that caging the $N$-terminal tyrosine in LE with the CNV group (CNV-Y-LE) afforded rapid photorelease in brain slices to activate MORs with good sensitivity to UV light (Banghart, He and Sabatini, 2018).

We therefore took an analogous approach to synthesize CNV-Y-DAMGO (4). Synthesis commenced with Boc-protection of the $N$-terminal amine of commercially available DAMGO, which proceeded in high yield (Scheme 2). Without protecting the Cterminal glyol, $N$-Boc-protected DAMGO was then selectively alkylated on the tyrosine phenol using (TMSE)-carboxynitroveratryl bromide (6), followed by simultaneous deprotection of the $N$-terminus and carboxylic acid using TFA in DCM. This three-step synthesis readily afforded milligram quantities of CNV-Y-DAMGO in $\sim 45 \%$ overall yield.

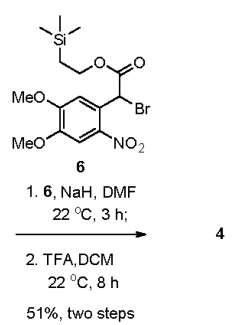

Scheme 2. Synthesis of CNV-Y-DAMGO. 
We next evaluated the activity of CNV-Y-DAMGO at MORs using the GloSensor assay of $\mathrm{G}_{\alpha}$ signaling in HEK293T cells (Figure 1). Whereas we found the $\mathrm{EC}_{50}$ of DAMGO to be $1.5 \mathrm{nM}$ in this assay, the $\mathrm{EC}_{50}$ of CNV-Y-DAMGO was $1.7 \mu \mathrm{M}$. This $\sim 1$,ooofold reduction in potency is similar to that observed when caging $L E$ in the same way, suggesting that $\mathrm{CNV}-\mathrm{Y}-\mathrm{DAMGO}$ is sufficiently inactive to produce strong photoactivation of MORs with light.

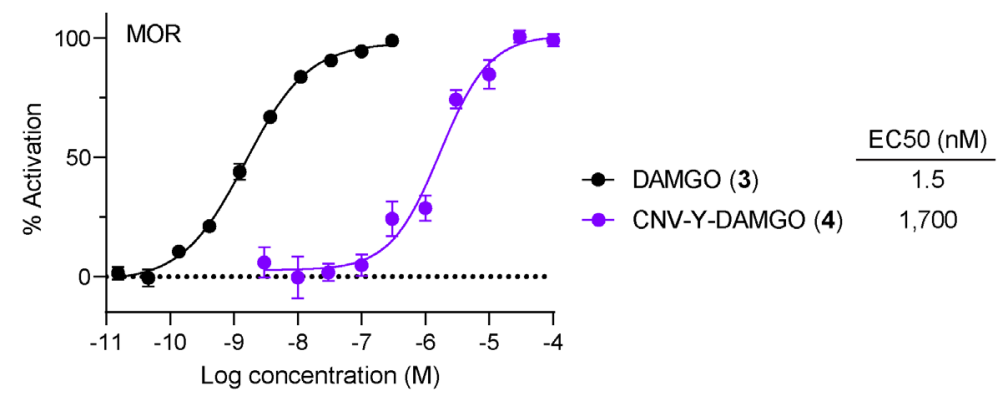

Figure 1. Activity of CNV-Y-DAMGO at the mu opioid receptor. Dose response-curves were obtained using a Glo-Sensor assay of cAMP signaling in HEK293T cells ( $\mathrm{n}=12$ wells per data point). Data were normalized to the maximal response to DAMGO $(1 \mu \mathrm{M})$ and are expressed as the mean \pm SEM.

To validate the utility of CNV-Y-DAMGO for probing native opioid receptors in brain tissue, we performed whole cell voltage clamp recordings from hippocampal neurons in acute brain slices taken from adolescent mice (Figure 2A). We previously reported that electrically-evoked synaptic inhibition in the perisomatic region of CA1 pyramidal neurons is strongly suppressed by both MOR and DOR agonists (Banghart, He and Sabatini, 2018). We first verified the inactivity of CNV-Y-DAMGO by recording inhibitory post-synaptic currents (IPSCs) during bath application of either DAMGO (1 $\mu \mathrm{M})$ or CNV-Y-DAMGO $(1 \mu \mathrm{M})$. Whereas DAMGO suppressed IPSC amplitude by $\sim 70 \%$, CNV-Y-DAMGO had no discernable effect on synaptic transmission (Figure 2B) (DAMGO: $0.70 \pm$ 0.02; CNV-Y-DAMGO: -0.046 \pm 0.05; p < 0.0001, Mann-Whitney test). We next probed the effects of illumination with $5 \mathrm{~ms}$ flashes of light emitted from a $355 \mathrm{~nm}$ laser, applied 2 seconds prior to an electrical stimulus. Similar to caged LE, photolysis of CNV-Y-DAMGO produced a rapid suppression of inhibitory synaptic transmission that reversed over the course of several minutes (Figure 2C). Presumably, the rate of reversal reflects diffusional clearance of the uncaged DAMGO from the photolysis site. Consistent with effect of DAMGO photorelease being mediated entirely 
by MORs, the optically-evoked suppression of synaptic transmission was completely

blocked by the inclusion of the

selective MOR antagonist

CTAP in the bath (Figure 2D)

(+UV: $0.61 \pm 0.05 ;+\mathrm{UV}$

+CTAP: $-0.05 \pm 0.10, \mathrm{p}=$

o.0o1, Mann-Whitney test).

Taken together, these results indicate that CNV-Y-DAMGO can be used to reliably activate endogenous MORs in brain tissue using light. Importantly, because DAMGO is selective for MORs, its use does not require the addition of antagonists for other receptors. Because the photolysis involves cleavage of a phenolic ether, the kinetics of photorelease are fast, similar to CYLE and CNVY-LE (Banghart, He and Sabatini, 2018). Like other photoactivatable probes based on dialkoxynitrobenzyl caging groups, CNV-Y-DAMGO

should be amenable to photoactivation with low-cost LEDs that emit wavelengths ranging from 365-405 $\mathrm{nm}$. It should also interface well with
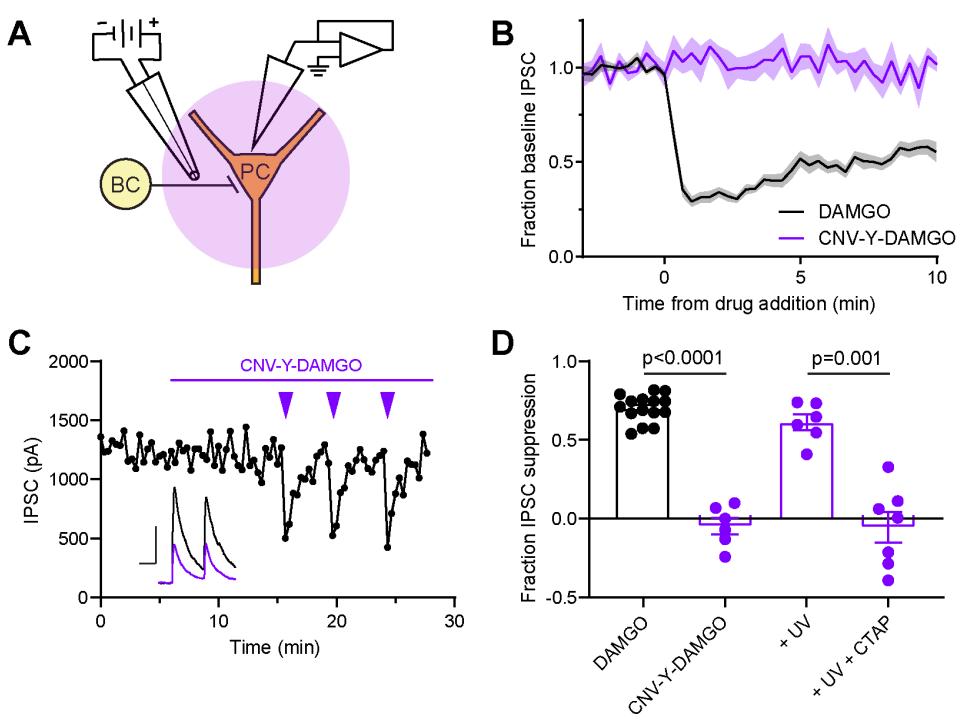

Figure 2. CNV-Y-DAMGO uncaging suppresses synaptic transmission in hippocampal brain slices via activation of the mu opioid receptor. A. Schematic of the experimental configuration for photo-uncaging of CNV-YDAMGO while recording electrically-evoked inhibitory synaptic transmission from basket cells (BC) impinging on pyramidal cells (PC). B. Baseline-normalized, average inhibitory post-synaptic current (IPSC) amplitude over time during bath application of DAMGO ( $\mathrm{n}=15$ cells from 14 mice) or CNV-Y-DAMGO ( $\mathrm{n}=6$ cells from 4 mice). $\mathbf{C}$.

Representative example of IPSC amplitude over time during bath application of CNV-Y-DAMGO $(1 \mu \mathrm{M})$ and repeated photolysis using 355 laser flashes ( $84 \mathrm{~mW}, 5 \mathrm{~ms}$ ). Inset: Example IPSCs immediately before (black) and after (purple) CNV-Y-DAMGO uncaging. Scale bars: $\mathrm{x}=25 \mathrm{~ms}, \mathrm{y}=500 \mathrm{pA}$.

D. Summary data comparing the fraction of baseline IPSC suppression in response to either DAMGO $(1 \mu \mathrm{M})$ bath application, CNV-Y-DAMGO $(1 \mu \mathrm{M})$ bath application, CNV-YDAMGO uncaging, and CNV-DAMGO uncaging in the presence of the mu-selective antagonist CTAP $(1 \mu \mathrm{M})$ (DAMGO ( $\mathrm{n}=15$ cells from 14 mice), CNV-DAMGO $(\mathrm{n}=6$ cells from 4 mice), $+\mathrm{UV}$ ( $\mathrm{n}=6$ cells from 4 mice), $+\mathrm{UV}+$ CTAP ( $\mathrm{n}=7$ cells from 2 mice)). 
experiments involving fluorescence imaging, as it will not be photolyzed by the longer wavelengths used to excite green and red fluorophores, which includes two-photon excitation. Future efforts will explore modifications designed to improve compatibility with in vivo uncaging, which may involve further reducing residual activity in the caged form, and the use of caging groups that respond to longer wavelengths of light that better penetrate tissue.

\section{METHODS}

Chemical Synthesis and Characterization. High-resolution mass spectrometry data were obtained at the UCSD Chemistry and Biochemistry Mass Spectrometry Facility on an Agilent 6230 time-of flight mass spectrometer (TOFMS). CNV-Y-DAMGO was purified by reverse-phase chromatography to $>99.9 \%$ purity, used as a mixture of diastereomers, and found to be stable in the dark for at least $24 \mathrm{~h}$ in phosphate-buffered saline at pH 7.2. DAMGO was obtained from HelloBio (HB2409) and TMSE-CNVbromide (6) was synthesized according to a published procedure (Gilbert et al., 2007).

$N$-Boc-DAMGO (4): To a stirred solution of DAMGO (50 mg, $97 \mu \mathrm{mol})$ in 1,4dioxane/water $(3 / 1,300 \mu \mathrm{L})$ in an amber glass vial at $22{ }^{\circ} \mathrm{C}, 1 \mathrm{M} \mathrm{NaOH}$ in water $(97 \mu \mathrm{L}$, $97 \mu \mathrm{mol})$ was added followed by (Boc) $)_{2} \mathrm{O}(21 \mathrm{mg}, 96 \mu \mathrm{mol})$ in 1,4-dioxane $(5 \mathrm{O} \mu \mathrm{L})$. The reaction was monitored by HPLC. After $16 \mathrm{~h}$, the reaction mixture was concentrated under vacuum and the residual was purified by $\mathrm{C} 18$ column chromatography (water $/ \mathrm{CH}_{3} \mathrm{CN}$, $95 \% / 5 \% \rightarrow 100 \%)$. Relevant fractions were combined and concentrated under vacuum to give $N$-Boc-DAMGO as a white solid (54 mg, 90\%). LR-MS (ESI) m/z 636 [(M+Na)+, 100\%]. HR-MS m/z 636.3005 [M+Na]+ (calcd for $\mathrm{C}_{31} \mathrm{H}_{43} \mathrm{~N}_{5} \mathrm{O}_{8} \mathrm{Na}, 636.3004$ ).

$N$-Boc-TMSE-CNV-Y-DAMGO: To a stirred solution of $N$-Boc-DAMGO (50 mg, $81 \mu \mathrm{mol}$ ) in anhydrous DMF (500 $\mu \mathrm{L}), \mathrm{NaH}$ (60\% in mineral oil, $3.3 \mathrm{mg}, 82 \mu \mathrm{mol})$ was added slowly. The mixture was stirred at o ${ }^{\circ} \mathrm{C}$ for $0.5 \mathrm{~h}$ followed by the addition of TMSE-CNVbromide $(6,34 \mathrm{mg}, 81 \mu \mathrm{mol})$ in anhydrous DMF (100 $\mu \mathrm{L})$ dropwise. The mixture was stirred under nitrogen and warmed up to $22^{\circ} \mathrm{C}$. The reaction was monitored by HPLC. After $3 \mathrm{~h}$, a drop of $\mathrm{MeOH}$ was added to quench the reaction. The reaction mixture was concentrated under vacuum and the residual was purified by C18 column 
chromatography (water $/ \mathrm{CH}_{3} \mathrm{CN}, 95 \% / 5 \% \rightarrow 100 \%$ ). Relevant fractions were combined and concentrated under vacuum to give $N$-Boc-TMSE-CNV-DAMGO as a white solid (67 mg, 87\%). LR-MS (ESI) m/z $975\left[(\mathrm{M}+\mathrm{Na})^{+} \text {, 100\%]. HR-MS m/z 975.4145 [M+Na }\right]^{+}$(calcd for $\left.\mathrm{C}_{46} \mathrm{H}_{64} \mathrm{~N}_{6} \mathrm{O}_{14} \mathrm{SiNa}, 975.4142\right)$.

CNV-Y-DAMGO (6): To a stirred solution of N-Boc-TMSE-CNV-DAMGO (6o mg, 63 $\mu \mathrm{mol})$ in DCM $(200 \mu \mathrm{L})$, TFA $(400 \mu \mathrm{L})$ was added. The reaction was monitored by HPLC. After $8 \mathrm{~h}$, the reaction mixture was concentrated under vacuum and the residual was purified by $\mathrm{C} 18$ column chromatography (water/ $\mathrm{CH}_{3} \mathrm{CN}, 95 \% / 5 \% \rightarrow 100 \%$ ). Relevant fractions were combined and concentrated under vacuum to give CNV-Y-DAMGO as a white solid (27 mg, 58\%). LR-MS (ESI) m/z 753 [(M+H)+, 60\%], 775 [(M+Na)+, 100\%]. HR-MS m/z 753.3086 [M+H]+ (calcd for $\left.\mathrm{C}_{36} \mathrm{H}_{45} \mathrm{~N}_{6} \mathrm{O}_{12}, 753.3090\right)$.

GloSensor Assay. Human embryonic kidney 293T cells were grown in complete DMEM (Dulbecco's modified Eagle’s medium (Invitrogen, Carlsbad, CA) containing 5\% fetal bovine serum (Corning), $50 \mathrm{U} / \mathrm{mL}$ Penicillin-Streptomycin (Invitrogen), and $1 \mathrm{mM}$ sodium pyruvate (Corning) and maintained at $37{ }^{\circ} \mathrm{C}$ in an atmosphere of $5 \% \mathrm{CO}_{2}$ in 10 cm TC dishes. Media in $10 \mathrm{~cm}$ TC dishes with HEK 293T cells (at around 70\% confluence) were replaced with Opti-MEM (Invitrogen). Then the SSF-MOR plasmid (Tanowitz and Von Zastrow, 2003), cAMP-dependent GloSensor reporter plasmid (-22F cAMP plasmid, Promega, E2301), and Lipofectamine 2000 (Invitrogen) in Opti-MEM were added. The dishes with transfection media were incubated at $37^{\circ} \mathrm{C}$ in an atmosphere of $5 \% \mathrm{CO}_{2}$ for 6 $\mathrm{h}$ before replacing media with complete DMEM. After incubating at $37{ }^{\circ} \mathrm{C}$ in an atmosphere of $5 \% \mathrm{CO}_{2}$ for $16 \mathrm{~h}$, transfected cells were plated in ploy- $D$-lysine coated 96well plates at $\sim 40$, ooo cells/well and incubated at $37{ }^{\circ} \mathrm{C}$ in an atmosphere of $5 \% \mathrm{CO}_{2}$ for $16 \mathrm{~h}$. On the day of assay, media in each well were replaced with $50 \mu \mathrm{L}$ of assay buffer (20 mM HEPES, 1x HBSS, pH 7.2, 2 g/L $D$-glucose), followed by addition of $25 \mu \mathrm{L}$ of 4x drug solutions for $15 \mathrm{~min}$ at $37{ }^{\circ} \mathrm{C}$. To measure agonist activity for MOR, $25 \mu \mathrm{L}$ of $4 \mathrm{mM}$ luciferin (Assay Reagent, Promega, E1291) supplemented with isoproterenol at a final concentration of $200 \mathrm{nM}$ was added, and luminescence counting was done after 25 min. 
Brain Slice Preparation. Animal handling protocols were approved by the UC San Diego Institutional Animal Care and Use Committee. Male and female postnatal day 15-35 mice on a C57/Bl6 background were anesthetized with isoflurane and decapitated, and the brain was removed, blocked, and mounted in a VT10ooS vibratome (Leica Instruments). Horizontal slices $(300 \mu \mathrm{m})$ were prepared in ice-cold choline-ACSF containing (in mM) $25 \mathrm{NaHCO}_{3}, 1.25 \mathrm{NaH} 2 \mathrm{PO} 4,2.5 \mathrm{KCl}, 7 \mathrm{MgCl}$, 25 glucose, 0.5 $\mathrm{CaCl} 2,110$ choline chloride, 11.6 ascorbic acid, and 3.1 pyruvic acid, equilibrated with 95\% O2/5\% CO2. Slices were transferred to a holding chamber containing oxygenated artificial cerebrospinal fluid (ACSF) containing (in mM) $127 \mathrm{NaCl}, 2.5 \mathrm{KCl}, 25 \mathrm{NaHCO}$, 1.25 $\mathrm{NaH}_{2} \mathrm{PO}_{4}, 2 \mathrm{CaCl} 2,1 \mathrm{MgCl} 2$, and 10 glucose, osmolarity 290. Slices were incubated at $32{ }^{\circ} \mathrm{C}$ for $30 \mathrm{~min}$ and then left at room temperature until recordings were performed.

Electrophysiology. All recordings were performed within $5 \mathrm{~h}$ of slice cutting in a submerged slice chamber perfused with ACSF warmed to $32{ }^{\circ} \mathrm{C}$ and equilibrated with 95\% O2/5\% CO2. Whole-cell voltage clamp recordings were made with an Axopatch $700 B$ amplifier (Axon Instruments). Data were filtered at $3 \mathrm{kHz}$, sampled at $10 \mathrm{kHz}$, and acquired using National Instruments acquisition boards and a custom version of ScanImage written in MATLAB (Mathworks). Cells were rejected if holding currents exceeded -200 pA or if the series resistance (<25 M 2 ) changed during the experiment by more than 20\%. Patch pipets (2.5-3.5 M $\Omega$ ) were filled with an internal solution containing (in mM) 135 CsMeSO3, 10 HEPES, 1 EGTA, 3.3 QX-314 (Cl - salt), 4 MgATP, 0.3 Na-GTP, and $8 \mathrm{Na} 2$ phosphocreatine (pH 7.3, $295 \mathrm{mOsm} / \mathrm{kg}$ ). Cells were held at $\mathrm{o} \mathrm{mV}$ to produce outward currents. Excitatory transmission was blocked by the addition to the ACSF of NBQX (10 $\mu \mathrm{M})$ and CPP (10 $\mu \mathrm{M})$.To electrically evoke IPSCs, stimulating electrodes pulled from theta glass with $\sim 5 \mu \mathrm{m}$ tip diameters were placed at the border between stratum pyramidale and stratum oriens nearby the recorded cell $(\sim 50-150 \mu \mathrm{m})$ and a two brief pulses (0.5 ms, 50-300 $\mu \mathrm{A}, 50 \mathrm{~ms}$ interval) were delivered every $20 \mathrm{~s}$.

UV Photolysis. Uncaging was carried out using $5 \mathrm{~ms}$ flashes of collimated full-field illumination with a $355 \mathrm{~nm}$ laser, as previously described. Light powers in the text 
correspond to measurements of a $10 \mathrm{~mm}$ diameter collimated beam at the back aperture of the objective. Beam size coming out of the objective onto the sample was $3900 \mu^{2}$.

Data Analysis. Electrophysiology data were analyzed in Igor Pro (Wavemetrics). Peak current amplitudes were calculated by averaging over a $2 \mathrm{~ms}$ window around the peak of the IPSC. To determine magnitude of modulation by DAMGO uncaging (\%IPSC suppression), the IPSC peak amplitude immediately after a flash was divided by the average peak amplitude of the three IPSCs preceding the light flash. The effects of drugs on IPSC suppression were calculated as the average \%IPSC suppression 2-3 minutes after drug addition. Summary values are reported as mean \pm SEM. All data are treated as non-parametric and specific statistical tests and corrections are described for each figure in the text and figure legends.

\section{AUTHOR INFORMATION}

Corresponding Author

\section{*E-mail: mbanghart@ucsd.edu}

\section{ORCID}

Xiang Ma: 0000-0002-9164-8608

Xinyi Jenny He: oooo-0002-388400596

Matthew R. Banghart: oooo-ooo1-7248-2932

\section{Author contributions}

X.M, X.J.H and M.R.B. conceived of the project. X.M. designed and synthesized CNV-YDAMGO and performed the GloSensor assays. X.J.H. designed and conducted the brain slice electrophysiology experiments and analyzed the data. All authors contributed to the writing of the manuscript.

\section{Funding}

This work was supported by the National Institute of Neurological Disorders and Stroke and the National Institute of Mental Health (Uo1NS113295 to M.R.B.), the National 
Institute of General Medical Sciences (T32GMoo7240 to X.J.H.), the Brain \& Behavior Research Foundation (M.R.B), the Esther A. \& Joseph Klingenstein Fund \& Simons Foundation (M.R.B), and the Rita Allen Foundation (M.R.B.).

\section{Notes}

The authors declare no competing financial interests.

\section{ACKNOWLEDGMENTS}

We would like to thank Eric Berg and Aryanna Layden for technical support, and Desiree Johnson and Shannan McClain and Jeffry Isaacson for helpful discussions.

\section{REFERENCES}

Arttamangkul, S. et al. (2018) 'Cellular tolerance at the $\mu$-opioid receptor is phosphorylation dependent.', eLife, 7. doi: 10.7554/eLife.34989.

Banghart, M. R. et al. (2013) 'Caged naloxone reveals opioid signaling deactivation kinetics.', Molecular pharmacology, 84(5), pp. 687-95. doi: 10.1124/mol.113.088096.

Banghart, M. R. et al. (2015) 'Enkephalin Disinhibits Mu Opioid Receptor-Rich Striatal Patches via Delta Opioid Receptors.', Neuron, 88(6), pp. 1227-39. doi:

10.1016/j.neuron.2015.11.010.

Banghart, M. R., He, X. J. and Sabatini, B. L. (2018) 'A Caged Enkephalin Optimized for Simultaneously Probing Mu and Delta Opioid Receptors.', ACS chemical neuroscience, 9(4), pp. 684-69o. doi: 10.1021/acschemneuro.7boo485.

Banghart, M. R. and Sabatini, B. L. (2012) 'Photoactivatable neuropeptides for spatiotemporally precise delivery of opioids in neural tissue.', Neuron, 73(2), pp. 24959. doi: 10.1016/j.neuron.2011.11.016.

Cahill, C. M. and Ong, E. (2018) 'Evidence and function relevance of native DOR-MOR heteromers', in Handbook of Experimental Pharmacology. Springer New York LLC, pp. 
115-127. doi: 10.1007/164_2018_112.

Ellis-Davies, G. C. R. (2007) 'Caged compounds: photorelease technology for control of cellular chemistry and physiology', Nature Methods, 4(8), pp. 619-628. doi: 10.1038/nmeth1072.

Font, J. et al. (2017) 'Optical control of pain in vivo with a photoactive mGlu5 receptor negative allosteric modulator', eLife. eLife Sciences Publications Ltd, 6. doi: 10.7554/eLife.23545.

Gilbert, D. et al. (2007) 'Caged capsaicins: New tools for the examination of TRPV1 channels in somatosensory neurons', ChemBioChem. John Wiley \& Sons, Ltd, 8(1), pp. 89-97. doi: 10.1002/cbic.200600437.

Gomes, I. et al. (2020) 'Biased signaling by endogenous opioid peptides', Proceedings of the National Academy of Sciences of the United States of America. National Academy of Sciences, 117(21). doi: 10.1073/pnas.2000712117.

Handa, B. K. et al. (1981) 'Analogues of $\beta$-LPH61-64 posessing selective agonist activity at $\mu$-opiate receptors', European Journal of Pharmacology. Elsevier, 70(4), pp. 531540. doi: 10.1016/0014-2999(81)90364-2.

He, X. J. et al. (2021) 'Convergent, functionally independent signaling by mu and delta opioid receptors in hippocampal parvalbumin interneurons', bioRxiv. Cold Spring Harbor Laboratory, p. 2021.04.23.441199. doi: 10.1101/2021.04.23.441199.

Kow, L. M. et al. (2002) 'Potentiation of the excitatory action of NMDA in ventrolateral periaqueductal gray by the $\mu$-opioid receptor agonist, DAMGO', Brain Research. Brain Res, 935(1-2), pp. 87-102. doi: 10.1016/Sooo6-8993(02)02532-5.

Manglik, A. et al. (2012) 'Crystal structure of the $\mu$-opioid receptor bound to a morphinan antagonist', Nature, 485(7398), pp. 321-326. doi: 10.1038/nature10954. 
Nicoll, R. A., Alger, B. E. and Jahr, C. E. (1980) 'Enkephalin blocks inhibitory pathways in the vertebrate CNS.', Nature, 287(5777), pp. 22-5.

Paoletti, P., Ellis-Davies, G. C. R. and Mourot, A. (2019) 'Optical control of neuronal ion channels and receptors', Nature Reviews Neuroscience, 20(9), pp. 514-532. doi: 10.1038/s41583-019-0197-2.

Quillinan, N. et al. (2011) 'Recovery from $\mu$-opioid receptor desensitization after chronic treatment with morphine and methadone', Journal of Neuroscience. J Neurosci, 31(12), pp. 4434-4443. doi: 10.1523/JNEUROSCI.4874-10.2011.

Rodríguez-Mũoz, M. et al. (2012) 'The Mu-opioid receptor and the NMDA receptor associate in PAG neurons: Implications in pain control', Neuropsychopharmacology. Neuropsychopharmacology, 37(2), pp. 338-349. doi: 10.1038/npp.2011.155.

Tanowitz, M. and Von Zastrow, M. (2003) 'A Novel Endocytic Recycling Signal That Distinguishes the Membrane Trafficking of Naturally Occurring Opioid Receptors', Journal of Biological Chemistry. Elsevier, 278(46), pp. 45978-45986. doi: 10.1074/jbc.M304504200.

Taura, J. et al. (2018) 'Remote control of movement disorders using a photoactive adenosine A 2A receptor antagonist', Journal of Controlled Release. Elsevier B.V., 283, pp. 135-142. doi: 10.1016/j.jconrel.2018.05.033.

Toll, L. et al. (1998) 'Standard binding and functional assays related to medications development division testing for potential cocaine and opiate narcotic treatment medications.', NIDA research monograph, 178, pp. 440-66.

Williams, J. T. (2014) 'Desensitization of Functional -Opioid Receptors Increases Agonist Off-Rate', Molecular Pharmacology, 86(1), pp. 52-61. doi: 10.1124/mol.114.092098. 


\section{FIGURES}<smiles>CC(C)C[C@H](NC(=O)[C@H](Cc1ccccc1)NC(=O)CNC(=O)CNC(=O)C(N)Cc1ccc(O)cc1)C(=O)O</smiles>

1

$\left[\right.$ Leu $\left.^{5}\right]$-enkephalin

(LE)<smiles>C[C@H](NC(=O)[C@H](N)Cc1ccc(O)cc1)C(=O)NCC(=O)N(C)[C@H](Cc1ccccc1)C(=O)NCCO</smiles>

3

[D-Ala2, N-MePhe4, Gly-ol]-enkephalin (DAMGO)<smiles>CC(C)C[C@H](NC(=O)[C@H](Cc1ccccc1)NC(=O)CNC(=O)CNC(=O)[C@H](N)Cc1ccc(OC(C(=O)O)c2ccccc2[N+](=O)[O-])cc1)C(=O)O</smiles>

(carboxy-nitrobenzyl)-tyrosine LE (CYLE)<smiles>COc1cc(OC)c([N+](=O)[O-])cc1C(Oc1ccc(C[C@H](N)C(=O)N[C@@H](C)C(=O)NCC(=O)N(C)[C@@H](Cc2ccccc2)C(=O)O)cc1)C(=O)NCCO</smiles>

(carboxy-nitroveratryl)-tyrosine DAMGO (CNV-Y-DAMGO)

\section{Scheme 1. Design of a caged DAMGO based on caged [Leu5]-enkephalin.}




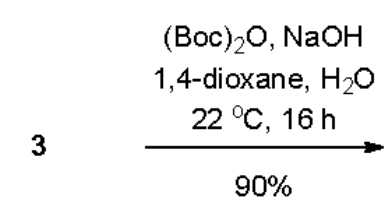

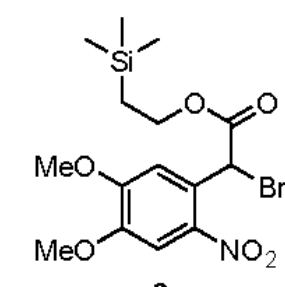

6

1. 6, NaH, DMF $22{ }^{\circ} \mathrm{C}, 3 \mathrm{~h}$;

2. TFA,DCM $22^{\circ} \mathrm{C}, 8 \mathrm{~h}$

$51 \%$, two steps

\section{Scheme 2. Synthesis of CNV-Y-DAMGO.}




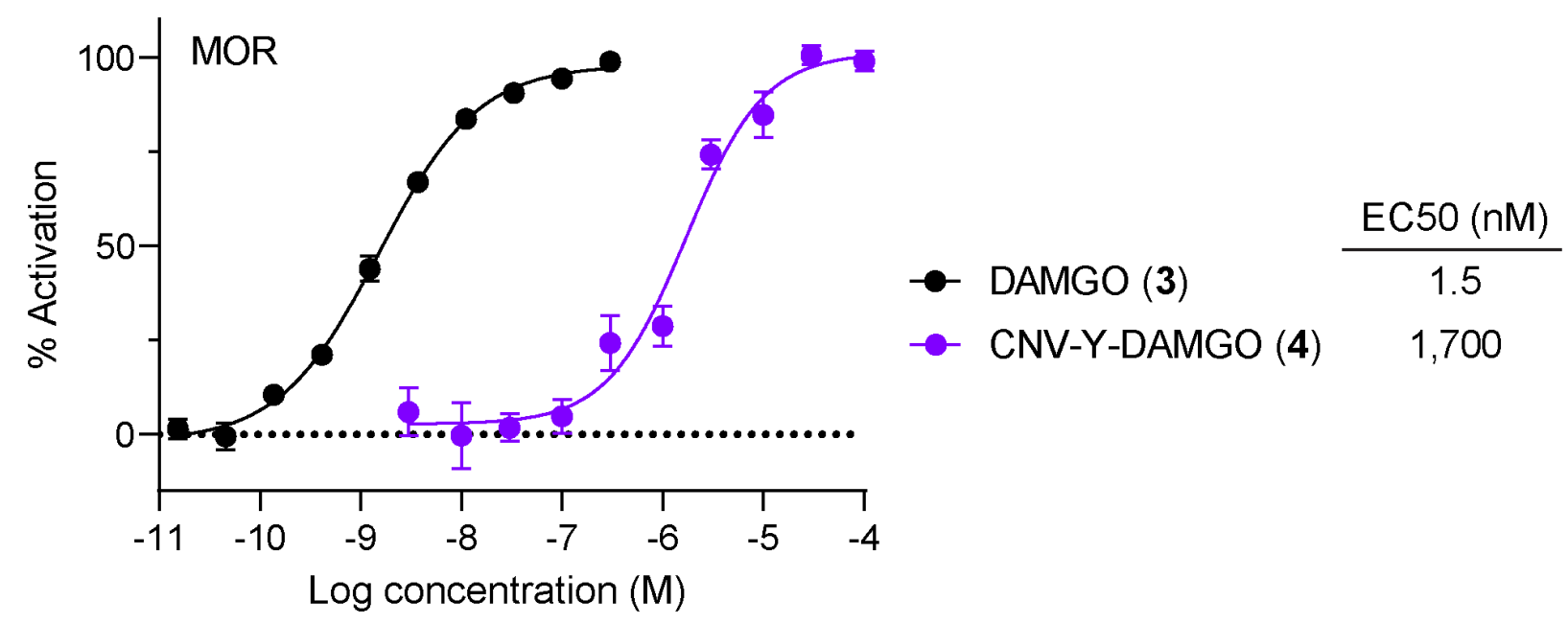

Figure 1. Activity of caged DAMGO at the mu opioid receptor. Dose responsecurves were obtained using a Glo-Sensor assay of cAMP signaling in HEK293T cells ( $n=12$ wells per data point). Data were normalized to the maximal response to DAMGO $(1 \mu \mathrm{M})$ and are expressed as the mean \pm SEM. 

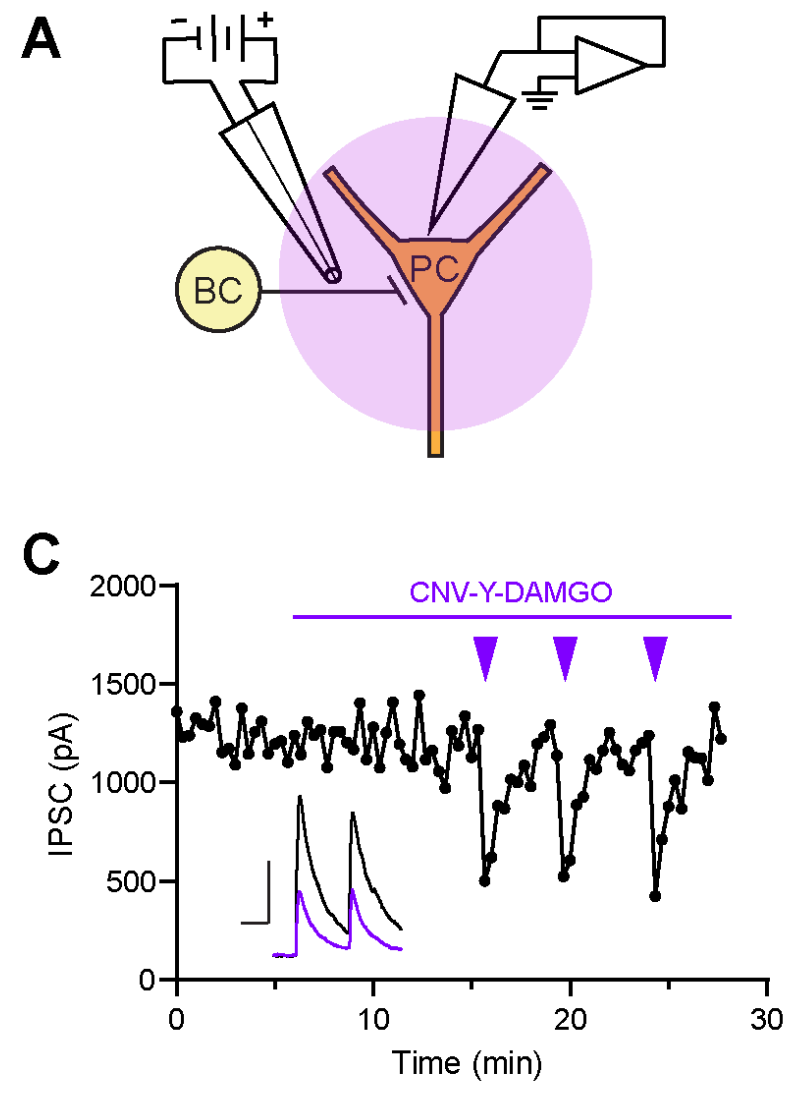

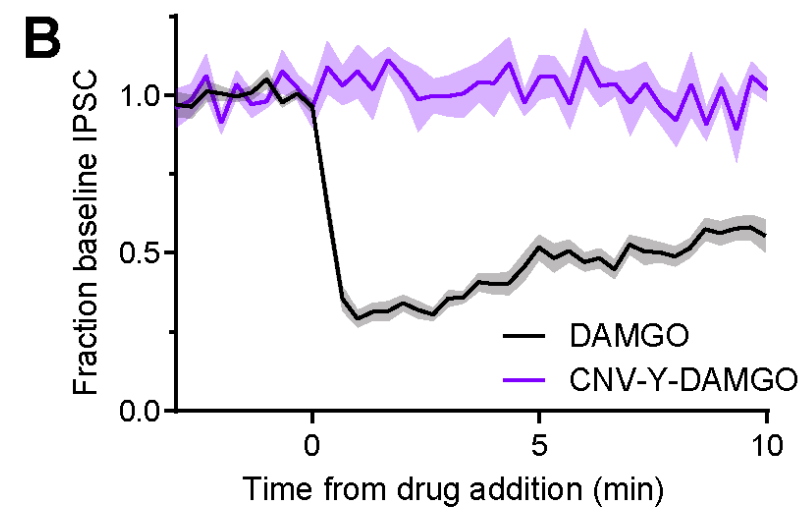

D

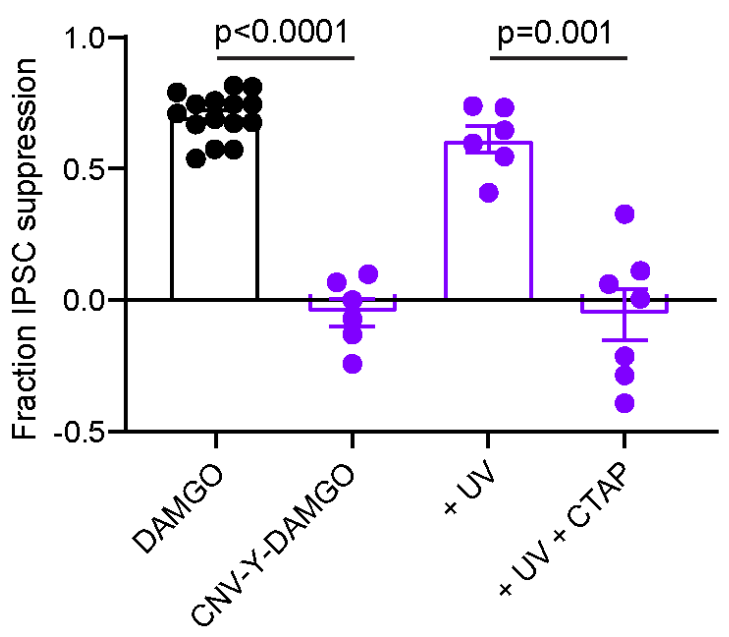

Figure 2. CNV-Y-DAMGO uncaging suppresses synaptic transmission in hippocampal brain slices via activation of the mu opioid receptor. $A$.

Schematic of the experimental configuration for photo-uncaging of CNV-Y-DAMGO while recording electrically-evoked inhibitory synaptic transmission from basket cells (BC) impinging on pyramidal cells (PC). B. Baseline-normalized, average inhibitory post-synaptic current (IPSC) amplitude over time during bath application of DAMGO (n $=15$ cells from 14 mice) or CNV-Y-DAMGO ( $n=6$ cells from 4 mice). C. Representative example of IPSC amplitude over time during bath application of CNV-Y-DAMGO $(1 \mu \mathrm{M})$ and repeated photolysis using 355 laser flashes ( $84 \mathrm{~mW}, 5 \mathrm{~ms}$ ). Inset: Example IPSCs immediately before (black) and after (purple) CNV-Y-DAMGO uncaging. Scale bars: $\mathrm{x}=$ $25 \mathrm{~ms}, \mathrm{y}=500 \mathrm{pA}$. D. Summary data comparing the fraction of baseline IPSC suppression in response to either DAMGO $(1 \mu \mathrm{M})$ bath application, CNV-Y-DAMGO (1 $\mu \mathrm{M}$ ) bath application, CNV-Y-DAMGO uncaging, and CNV-DAMGO uncaging in the presence of the mu-selective antagonist CTAP $(1 \mu \mathrm{M})$ (DAMGO $(n=15$ cells from 14 
bioRxiv preprint doi: https://doi.org/10.1101/2021.09.13.460181; this version posted September 14, 2021. The copyright holder for this preprint (which was not certified by peer review) is the author/funder, who has granted bioRxiv a license to display the preprint in perpetuity. It is made available under aCC-BY-NC-ND 4.0 International license.

mice), CNV-DAMGO ( $\mathrm{n}=6$ cells from 4 mice), $+\mathrm{UV}(\mathrm{n}=6$ cells from 4 mice $),+\mathrm{UV}+$ CTAP ( $n=7$ cells from 2 mice)). 